\title{
The Effect of Therapy Containing Puzzle on Decreasing Anxiety of Hospitalized Children Aged 3-6 Years
}

\author{
$1^{\text {st }}$ Dini Rismala Dewi \\ Nursing Department \\ Universitas Muhammadiyah \\ Pringsewu \\ Jl. KH.Ghalib No.112 Pringsewu \\ 35373 Lampung Indonesia \\ dinirismaladewi02@gmail.com
}

\author{
$2^{\text {nd }}$ Arena Lestari \\ Nursing Department \\ Universitas Muhammadiyah \\ Pringsewu \\ Jl. KH.Ghalib No.112 Pringsewu \\ 35373 Lampung Indonesia
}

\author{
$3^{\text {rd }}$ Diny Vellyana \\ Nursing Department \\ Universitas Muhammadiyah \\ Pringsewu \\ J1. KH.Ghalib No.112 Pringsewu \\ 35373 Lampung Indonesia
}

\begin{abstract}
Anxiety is one of the psychological disorders that can occur in children undergoing hospitalization, this impact can interfere with growth and healing process in children that is playing is one of the non pharmacological therapies in children, one of the games is to arrange puzzles. The purpose of this study was to determine the effect of play therapy to arrange puzzles to decrease anxiety of hospitalized children aged 3-6 years in Alamanda room at Abdul Moloek Hospital Lampung. This study was a quasiexperimental study with village nonequivalent control group with design pre-test and post-test. This study used purposive sampling technique with an intervention group of 17 respondents while the control group 15 respondents. Playing Puzzle interventions performed for $\mathbf{4}$ consecutive days. This study used t-test method, data analysis from PAS (Pre school Anxiety Scale) instruments so that $\mathbf{p}$-value $=\mathbf{0 , 0 0 0}$ $<0,05$ shows that playing puzzle therapy have an effect on reducing hospitalitation anxiety in pre-school age children. This means that play therapy using puzzle therapy can be applied to children in reducing childrens anxiety at hospitalization.
\end{abstract}

Keywords - Therapy, Puzzle, Children

\section{INTRODUCTION}

Children are vulnerable and dependent creatures who are always curious, active, even hopeful, this is where the child's part of life begins for the next period (Nursalam, 2013). At preschool age, children's activity increases which often causes fatigue so that the range of illness due to weak immune system, until the child is required to undergo hospitalization. The number of incidents of children being treated in hospitals 57 million children every year where $75 \%$ experience trauma, in the form of fear and anxiety when undergoing hospitalization (James, 2010). UNICEF survey results in 2012, the percentage of children who undergo treatment in hospital by $84 \%$.

At this time the child sometimes experiences various experiences that are very traumatic and full of stress. The hospital environment is a cause of stress for children and parents, both the physical environment of the hospital such as buildings and wards, distinctive odor tools, the white clothes of health workers and the social environment, such as fellow pediatric patients or the interactions and attitudes of health care workers themselves (Supartini., 2004). At school age the cognitive level is higher compared to pre-school age children so that school-age children more easily understand the procedures given compared to preschool age (Wildianti, 2011). This hospital is a crisis situation for children, when the child is sick and hospitalized. This situation (hospitalization) occurs because the child tries to adapt to the foreign and new environment that is the hospital, so that the condition becomes stressful both for preschool age children see hospitalization as a frightening experience. When the child is undergoing treatment at the hospital, usually he will be banned from moving a lot and having lots of rest (Samiasih,2007) and it can also be said that the child interprets hospitalization as punishment and separation from parents as a loss of affection, the child's response to hospitalization creates obstacles in the implementation of care that will be given so that it hinders the healing process. This causes longer treatment time, even accelerating the occurrence of complications during treatment (Nursalam, 2011) usually children who are hospitalized (hospitalization) cause anxiety in these children.

Anxiety is an individual's subjective emotions and experiences, has its own strengths and is difficult to observe directly, nurses can identify anxiety through changes in patient behavior (Nursalam, 2011). The effects of hospitalization by the nature and severity of health problems, the child's condition and the degree of difference in activities and routines of daily life. Children who undergo treatment at the hospital will cause anxiety that occurs in children, children cannot be allowed, because this can have a negative impact on the child's health recovery process. One to hone child development by playing. Pre-school age games are usually associative, can develop motor coordination and require relationships with peers. Some research related to the game which states that the game has a positive effect on the treatment of children, and the types of games that can be given must be adjusted to the level of child maturity (Adriana, 2011).Some preschool age games include coloring 
pictures, drawing, puzzle building and building blocks. Puzzle is a game that requires patience and perseverance in arranging children. Through puzzle games children can make concepts in understanding the events in their environment well. Puzzle game is a type of game that is done alone and in groups, where children communicate with each other and interact in preparing puzzles. Puzzle games are included in one of the educational games, where the activity is fun, entertaining (Adriana, 2011)

\section{RESEARCH METHOD}

This type of research is quantitative research, using a quasi-experimental research design with non-equivalent control group design approach with pre-test and post-test design sampling according to age while the control group is not done randomly. The design of this study was made to see the effect of puzzle play therapy with a decrease in anxiety of pre-schoolers before and after being given a puzzle (Dharma \& Media, 2017). The number of samples in this study amounted to 17 patients aged toddlers who were treated one day at Abdul Moeloek Hospital in Lampung Province in Indonesia and the number of samples in the control group were 17 patients who were in different hospitals. The instrument used to measure the level of anxiety of children with 15 items checklist with a preschool anxiety scale (PAS) scale developed by Spence at al, while the experimental instrument used was a Jig Saw puzzle that was given for 4 consecutive days and took approximately $15-20$ minutes. Whereas in the control group patients were not given anxiety management interventions. Bivariate analysis in this study uses the Ttest, because the two variables are the same using the dependent variable in order to determine the effectiveness of compiling a puzzle in reducing anxiety of child hospitalization.

\section{RESEARCH RESULT AND DISCUSSION}

TABLE 1. AVERAGE FREQUENCY DISTRIBUTION ANXIETY LEVEL BEFORE AND AFTER INTERVENTION

\begin{tabular}{|c|c|c|c|c|c|c|c|}
\hline \multirow{2}{*}{ Class } & \multicolumn{2}{|c|}{ Mean } & \multicolumn{2}{c|}{ Min } & \multicolumn{2}{c|}{ Max } & Cl \\
\cline { 2 - 8 } & Before & After & Before & After & Before & After & $95 \%$ \\
\hline Control Group & 42.53 & 39.24 & 27.00 & 25 & 55.00 & 17 & \\
\hline Intervention Group & 34.12 & 26.82 & 27.00 & 50 & 40.00 & 42 & \\
\hline
\end{tabular}

Based on the average frequency distribution of children's anxiety levels prior to the intervention in the control group of 42.53 , with SD of 8.58 , and the average level of anxiety of children in the intervention group of 40.00 , with SD of 4.17 . The average frequency of children's anxiety levels after the intervention in the control group was 8.33 , with an SD of 1.15 , and the average anxiety level of children in the intervention group was 8.50, with an SD of 1.00 .

TABLE. 2 EFFECTS OF PLAY THERAPY ON DEVELOPING PUZZLES ON DECREASED ANXIETY IN CHILDREN IN HOSPITAL AGE (3-6 YEARS)

\begin{tabular}{|l|l|l|l|l|l|}
\hline & Mean & SD & T & CI & $p$-value \\
\hline Control Group & 39.24 & 7.10220 & \multirow{2}{*}{4.921} & \multirow{2}{*}{$95 \%$} & \multirow{2}{*}{0.000} \\
\cline { 1 - 3 } Intervention Group & 26.82 & 6.63547 & & \\
\hline
\end{tabular}

Based on the results of bivariate analysis the average anxiety level of children in the control group was 39.24 and the average anxiety level of children in the intervention group was 26.82, which means there was a difference of 12.42. T-test results obtained t-test of 4.921 and $\mathrm{t}$-table of 1.746 with $\mathrm{p}$-value $=0.000<0.05$. This states that Ha was accepted and $\mathrm{H} 0$ was rejected, which means that there was an effect of playing therapy in composing a puzzle on anxiety reduction in hospitalized children aged (3-6 years) in the Alamanda treatment room at Abdul Moeloek Hospital in Bandar Lampung in 2019.

The results showed the most control groups aged 3 and 4 years were 6 children $(35.3 \%)$ and the lowest was 6 years old namely 1 child (5.9\%), in the intervention group the most 3 years old were 7 people $(58.3 \%)$ and the lowest is 2 years old, 2 people $(16.7 \%)$. According by (Stuart, 2013) the ability of an individual to respond to the cause of anxiety is age. Someone who has a younger age is more easily disturbed by anxiety than someone older, but there are those who argue otherwise. In the control and intervention group each with a female gender is 9 people $(52.9 \%)$ and the lowest with a male gender is 8 people (47.1\%).

T-test value of 4.921 and t-table of 1.746 with $p$-value $=0.000<0.05$. This states that $\mathrm{Ha}$ is accepted and $\mathrm{H} 0$ is rejected, which means that there is an effect of playing therapy in composing a puzzle on anxiety reduction in children in hospitalization (3-6 years). The study by (Rahima, 2017) shows the influence of containing puzzle therapy on anxiety of preschoolers during hospitalization, where the average value of anxiety responses before being given puzzle therapy and after being given puzzle therapy has very big differences. So containing therapy with puzzle is very meaningful in reducing anxiety in children because it requires patience and perseverance in arranging children. 
Thus, play therapy is a form of therapy that helps children or young people to overcome problems in their lives by using media that can also be done in groups with children, other patients, therapy can be done individually by nurses or families who have trained (Adrina, and Handoko 2016). Alfiyanti (2007), researching about the effect of puzzle play therapy on anxiety levels of preschool children during nursing actions in the Lukman Room of Semarang Roemani Hospital, the results of this study indicate that there are significant differences between anxiety levels of preschool children during nursing actions before and after puzzle play therapy.

According to Misbah, (2011) Puzzles have many benefits, including improving the ability to think and make children learn to concentrate, Train hand and eye coordination Puzzles can train children's hand and eye coordination to match puzzle pieces and arrange them into one picture, Improve cognitive skills (cognitive skill) relating to the ability to learn and solve problems, expand knowledge, practice patience, and learn to socialize. The results of this study indicate that there is an effect of play therapy composing a puzzle on anxiety reduction in children in age hospitalization (3-6 years). This means that the implications of the study can be used as a nurse's reference in providing distraction to patient anxiety in order to achieve the maximum patient care process and shorten the patient's morbidity in the hospital. Playing is not just filling time but is a child's needs as well as food, care and love. By playing children will find their own strengths and weaknesses, interests, and ways to solve tasks in playing puzzle.

In accordance with the literature review results of facilitating play for hospitalized children through child life services conducted by Burns-Nader et al.,(2014) i.e. Play has been found to help children cope with the stressors such as hospitalization because it allows them to express their fears and anxiety in the manageable way.

\section{CONCLUSION}

Based on the findings above, the conclude of this study that containing puzzle could be used for increasing of nursing care program for anxiety toddler patient. As the distraction system, containing puzzle make the medication can run well because the patients will not have physichology problem.

\section{REFERENCES}

[1] Nursalam. (2013). anak dan tumbuh kembang. Jakarta: medikal book.

[2] James, J., Ghai, S., Sharma, N., 2012, Effectiveness of"Animated Cartoons" As ADistraction Strategy on Behavioural Response To Pain Perception Among Children Undergoing Venipuncture, Nursing and Midwifery Research Journal., 8(3):198-209.

[3] UNICEF. (2012). Indonesia laporan Tahunan. Geneva: UNICEF

[4] Supartini. (2004). kongsep dasar keperawatan anak. Jakarta: EGC.

[5] Wildianti, C. R . (2011). Pengaruh Senam Oak Terhadap Kecemasan Akibat Anak Hospitalisasi Pada Anak Usia Pra Sekolah Di Rumah Sakit Pantih Rapih Yogyakarta .Tesis Fakultas Keperawatan; Universitas Indonesia, 2011. Pengaruh Senam Otak Terhadap Kecemasan Akibat Anak hospitalisasi. Diakses dari http://lib.ui.ac.id/file? file=digital/20280300T\%20Christina\%20Ririn\%20Widianti.pdf
[6] Alfiyanti, Hartanti \& Samiasih. (2007). Vol 1. No.1. Pengaruh Terapy Bermain Terhadap Kecemasan Anak Prasekolah Selama Tindakan Keperawatan. Diakses tanggal 1 Januari 2015 dari HTTP://jurnal.unimus.ac.id

[7] Nursalam. (2011). anak dan tumbuh kembang. Jakarta: medika book

[8] Adriana, D. (2011). Tumbuh dan Terapi bermain pada anak. Jakarta: selemba medika.

[9] Dharma, K.K, \& Media. (2017). Metodologi Penelitian Keperawatan. Jakarta: Trans Info Media.

[10] Stuart, G.W, .\& Sunden, S,J,. (2013). Buku saku keperawatan jiwa. Jakarta: EGC.

[11] Rahima. (2017). pengaruh bermian edukatif dengan media puzzle terhadap perkembangan kognitif dalam mengenal bentuk warna pada anak pra sekolah di tk Aisyiyah. Diakses dari http://stikba.ac.id/journal/detail/128/pengaruh-permainanedukatif-dengan-media-puzzle-terhadap-perkembangan-kognitifdalam-mengenal-bentuk-dan-warna-pada-anak-prasekolah--ditk-aisyiyah-iv-kota-jambi.

[12] Burns - Nader S \& Hernandez - Reif (2014). Facilitating Play for Hospitalized Children Through Child Life Services. England: Routledge. Diakses dari http:/ www.tandfonline.com/page/terms-and-conditions 